N 6848 E97 1916 NMAA

\author{
SPECIAL
}

BITION CATALOGUE

CITY ART MUSEUM SAINT LOUIS

\title{
EXHIBITION OF \\ FRENCH AND BELGIAN ART FROM THE \\ PANAMA-PACIFIC INTERNATIONAL EXPOSITION, 1915
}

\section{4}

Opening, February 6, 1916

Series 1916

No. 4 


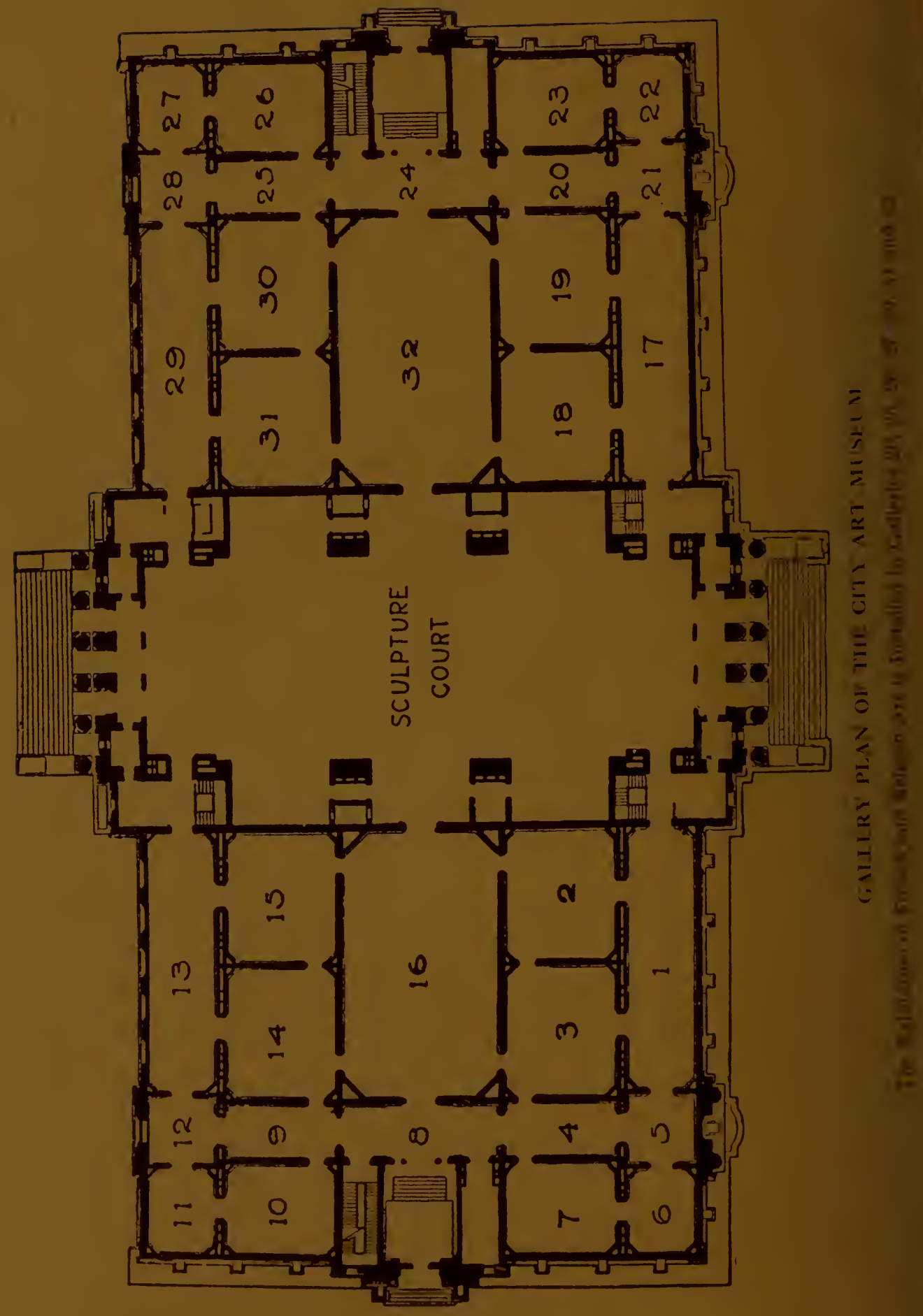




$N$ SPECIAL EXHIBITION CATALOGUE Series of 1916; No. 4 6848

$E 97$

1916

NMAA

\author{
EXHIBITION OF \\ FRENCH AND BELGIAN ART \\ FROM THE \\ PANAMA-PACIFIC INTERNATIONAL \\ EXPOSITION, 1915
}

\title{
NMAA/NPG LIBRARY \\ SEP 261990
}

SMITHSONIAN INSTITUTION

\section{CITY ART MUSEUM}

ST. LOUIS

FEBRUARY, 1916 


\section{THE CITY ART MUSEUM, ST. LOUIS}

ADMINISTRATIVE BOARD OF CONTROL

WILLIAM K. BIXBY

President

SAMUEL L. SHERER

Vice-President

DANIEL CATLIN

DAVID R. FRANCIS

MAX KOTANY

WILLIAM H. LEE

EDWARD MALLINCKRODT

CHARLES PARSONS PETTUS

THOMAS H. WEST

R. A. HOLLAND

Director

MADELEINE BORGGRAEFE

Secretary

CHARLES PERCY DAVIS

Curator 
$\mathrm{T}$ HE present Exhibition of French and Belgian Art which is being sent to various museums is the greater part of the French exhibit which was shown in the Palace of Fine Arts at the Panama-Pacific Exposition, and represents in a most instructive manner the general trend of French art at the present time. It was the desire of those responsible for the collection to exhibit chiefly works produced within the last fifteen years and by men of recognized ability of every school. The major portion of the works here assembled was selected from the Fine Arts Section; but a few judiciously chosen additions, including the Belgian paintings, were made from the retrospective exhibition in the French Pavilion.

It is fair to assume that all of the works presented are characteristic examples by the artists represented, and that they afford the American public an opportunity to study the typical, present-day art of France, the sort of art that one would expect to find assembled in the annual exhibitions of the Salon. Following as it does the big annual exhibitions of American paintings exhibited at most of our own museums, a splendid opportunity is given for comparison, and, as it were, to gauge our contemporary art. Moreover, it gives us an insight into the influences that tend to mould our own national art expression. It is no injustice to the other nations that have contributed so much to the upbuilding of those sound traditions upon which American art is founded to say that to France we are most deeply indebted. Our illustrious painters and sculptors-Saint Gaudens, Bartlett, Inness, Whistler, Sargent, and many others, a long succession of the most brilliant names in the history of American art-owe their success to the thorough training received at the hands of their French masters.

It is to such men as Manet and Monet and their co-workers that the world is indebted for the great school of impressionism-the school that taught us to see the beauties of 
light and atmosphere; the effect of which is manifest in the works of every artist of note in the civilized world. Such is the reward of that indomitable spirit which seeks the truth and perseveres against adverse criticism.

One sees in the art of France a fidelity, a vigor and a striving to depict the life of the people; and here we may add they have pointed the waý to that long-sought goalthe achievement of an American school of painting, a national art as distinctive from that of any other nation.

It is gratifying to note that this exhibition contains works by men of all schools. Paintings by the more conservative artists who still cling to academic principles are shown by the side of the works of the leaders of the newer movements; and here again is evidence of the tendency toward democracy-all have a hearing. America boasts of democracy, but France has shown us a real democracy, at least in art.

The City Art Museum and the citizens of St. Louis in general are greatly indebted to those in charge of the French Section of the Fine Arts Department of the Panama-Pacific Exposition for the privilege of this exhibition. That many of the men represented are in dire straits is well known, and a rare opportunity is afforded for the acquisition of works by some of the best painters of the present time. 


\section{PAINTINGS, WATER GOLORS AND DRAWINGS}

BY FRENGH ARTISTS

\section{ARTISTS}

AND TITLES

LOUIS-ÉMILE ADAN

I The Holy Fanilly

JULES ADLER

2 Christmas in the Faubourg

ALFRED-PIERRE AGACHE

3 The Sword

GEORGETTE AGUTTE

4 My Garden in Spring; from the Studio

5 The lake of Compfère, Haute Engadine Water Color

ALBERT ANDRÉ

6 The Old Castle

Lent by Messrs. Durand-Ruel

7 Recumbent Woman

Lent by Messrs. Durand-Ruel

J.-FRANCIS AUBURTIN

8 The Swan

9 Landscape

JOSEPH-MARIUS AVY

io The Last Pin Water Color

II Fruit 


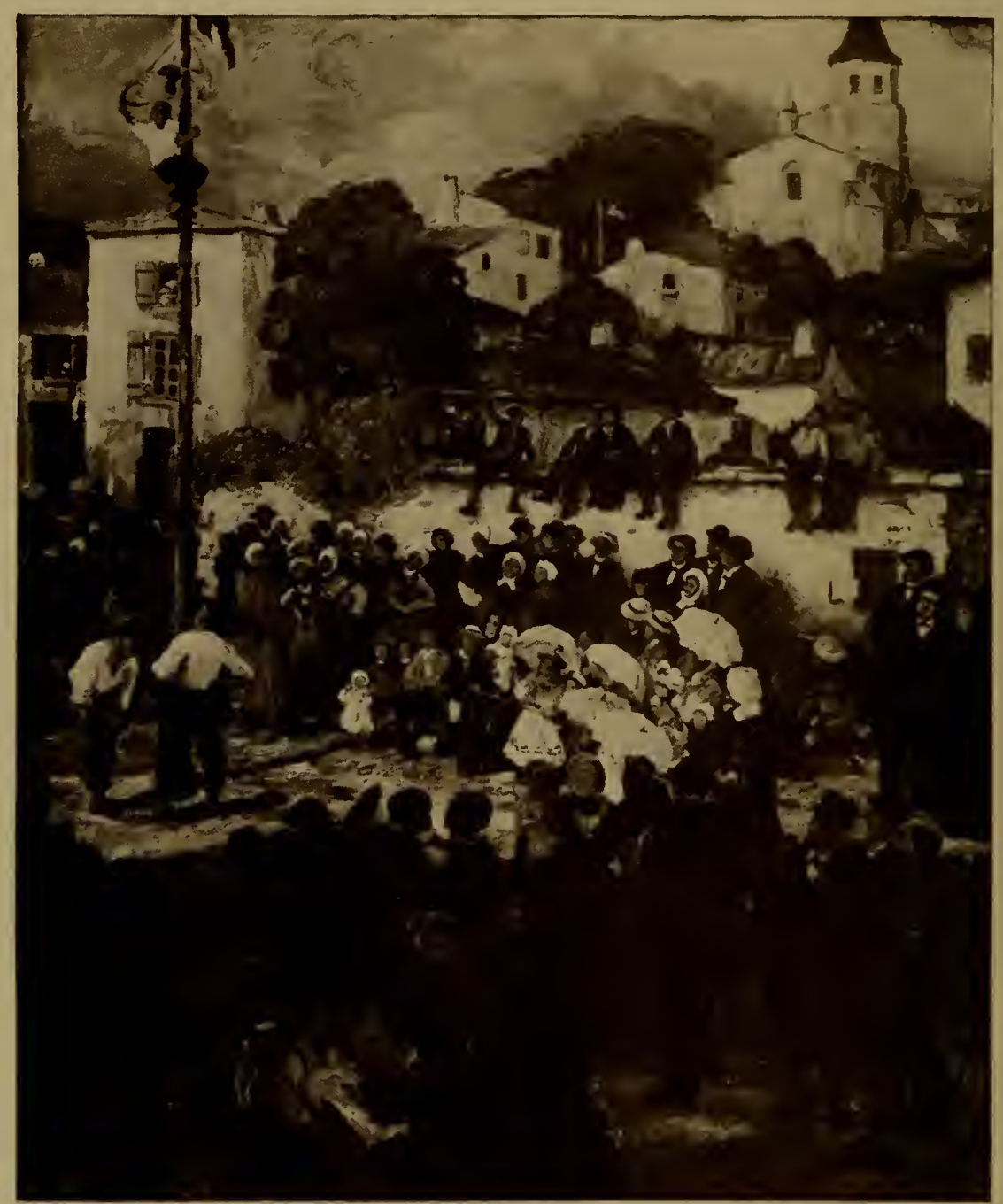

GASTON BALANDE

I3 The Greased Pole 
FRANCK-ANTOINE BAIL

I2 The Kitchens; Chateau Fleury-enBIERRE

GASTON BALANDE

I3 The Greased Pole

GEORGES BARBIER
14 Turandot Water Color
15 Gilles Water Color

FRANÇOIS-CHARLES BAUDE

i6 Communicants, Flanders

PAUL BAUDOÜIN

I7 Ivy Fresco on fibre cement

HUGUES DE BEAUMONT

i8 Room of the Collection of Henri Cain

i9 Corner of the Room: Jaceues Doucet Collection

JEAN BÉRAUD

20 The Widower

HIPPOLYTE BERTEAUX

2 I Goats Waiting to be Milked, Belle-ÍleeN'-Mer

22 The Wild Coast, Goulphar, Belle-Île-enMER 


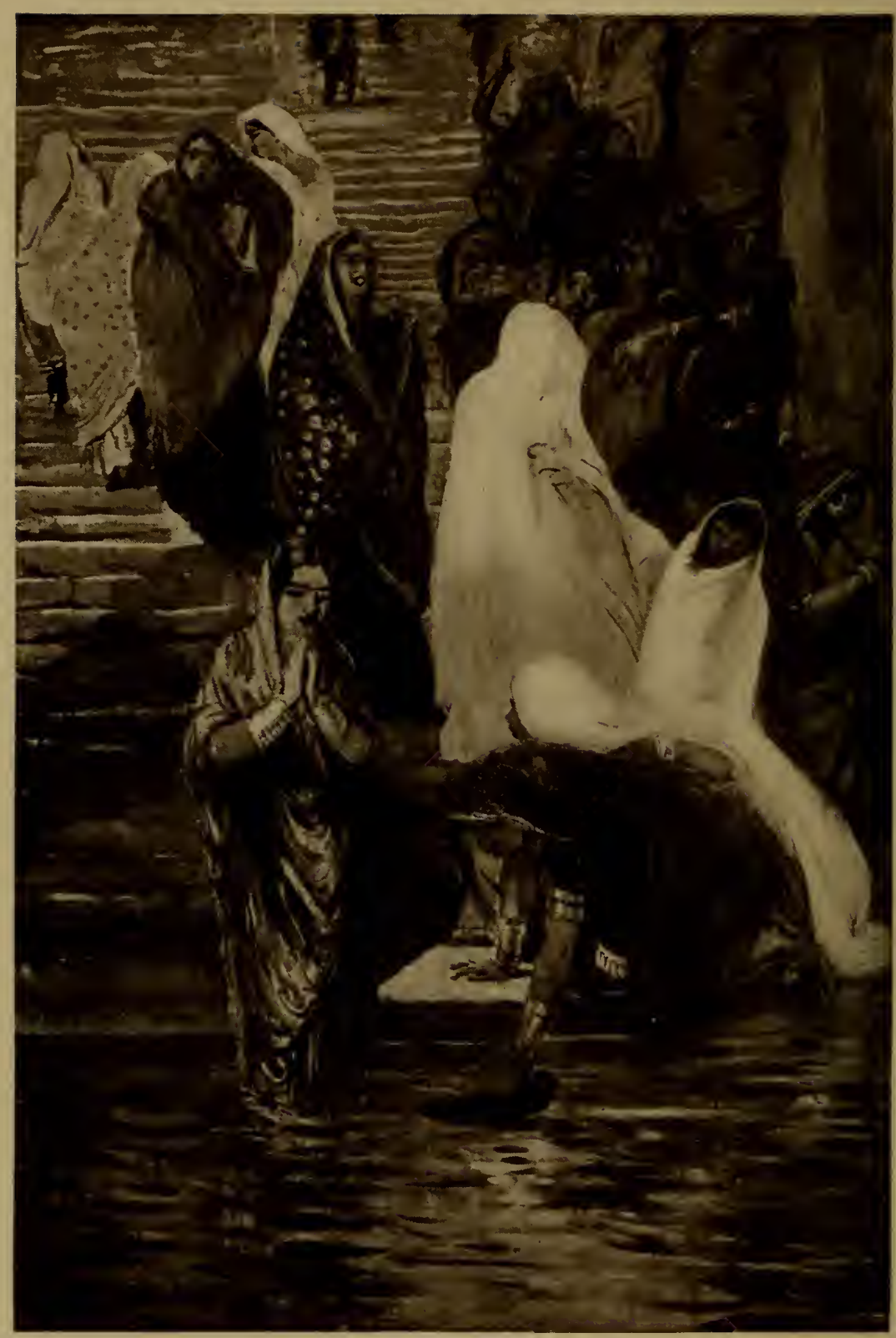

ALBERT BESNARD

26 ON THE Stairivay IN Benares 
ALBERT BESNARD

23 Woman Asleep

24 The GyPSY

25 Dancer with the Yellow Mask Gouache

26 On a Stairiway, Benares Gouache

27 A Street in Madeira Gouache

28 The Man in Pink Gouache

29 The Bracelet Seller Gouache

30 The Brahmin Gouache

3I The Procession of Langar Gouache

32 A Curio Dealer in Delhi Water Color

33 Study for the "Dancer with the Yellow MASK" Gouache

JACQUES-ÉMILE BLANCHE

34 Madame Ida Rubinstein in "ScheheraZADE" by Rimski Korsakoff

35 Portrait of Henry James

Lent by Mrs. Stanley McCormick

MAURICE BOMPARD

36 Persian Pottery

PIERRE BONNARD

37 Dining Room in the Country

Lent by Messrs. Bernheim

ÉMILE BOULARD

38 Hayricks

BERNARD BOUTET DE MONVEL

39 The Village

40 The Country Town 
LOUIS BRAQUAVAL

4I The Mouth of the Somme

ALEXIS DE BROCA

42 The Island of Arz, Brittany

ANDRÉ BROUILLET

43 Among the Dunes

Lent by Messrs. Bernheim

44 The Painter's House

Lent by Messrs. Bernheim

PAUL BUFFE'T

45 Meadows; Evening

ANTOUIN CALBET

46 Reading

HENRI CARO-DELVAILLE

47 The Lady with the Hydrangea

PIERRE CARRIER-BELLEUSE

48 The Ballet Slipper

KARL CARTIER

49 Evening; Moret-Sur-Loing

JULES-CYRILLE CAVÉ

50 Saint Cecilia in the Catacombs

JULES CAYRON

5 I Drawing Room of the Chateau

52 The Green Turban 


\section{JEAN-CHARLES CAZIN}

53 The House of Socrates

Lent by M. Knoedler, Paris

54 The Bear and the Garden Lover

Lent by M. Knoedler, Paris

MAURICE CHABAS

55 In Brittany

ANDRÉ CHAPUY

56 The Banks of the Marne

Lent by the French Government.

EUGÈNE CHIGOT

57 The Grand-Trianon, Versailles

GEORGES CLAIRIN

58 MOORISH WOMEN

RAPHAËL COLLIN

59 Nonchalance

MARCEL COSSON

60 The Salute

6i Dancing Girls

HENRI DABADIE

62 Summer; Bouzaréah, Algeria

63 The Straits of Ferlez; Brehat, Brittany

CHARLES-RENÉ DARRIEUX

64 Le Pardon of Tréboul-Goz, Douarnenez, BRITTANY

ANDRÉ DAUCHEZ

65 The Walled Town: Concarneau, Brittany

66 The Dark Pool, Finistère 


\section{GERMAIN DAVID-NILLET}

67 Notre Dame; Paris

68 Interior: Church of Saint-Maclou, Rouen

MAGDELEINE DAYOT

69 Still Life

LÉON DELACHAUX

70 The Convalescent

ANGÈLE DELASALLE

7 The Bois de Boulogne

MAURICE DENIS

72 Renaud and Armide

73 Communicants

74 NaUsicaA

Lent by Galerie E. Druet

75 Study FOR "NAUSicaA"

76 Tennis

Lent by Galerie E. Druet

77 Study For "Tennis"

78 The Bathers

Lent by Galerie E. Druet

79 Study for "The Bathers"

80 Tennis

Lent by Galerie E. Druet

8i Study For "Tennis"

82 THE ВеACH

Lent by Galerie E. Druet

83 Study for "The Beach"

84 The Cart

Lent by Galerie E. Druet

85 Study for "The Cart" 


\section{G. D'ESPAGNAT}

86. Little Garden in Sicily

Lent by Messrs. Durand-Ruel

GEORGES DESVALLIÈRES

87 SACREd Heart

Lent by Galerie E. Druet

MAXIME-PIERRE DETHOMAS

88 Yvonne

89 JeANNE

JEAN-ÈMILE DIDIER-TOURNE

$90 \quad W_{A R}$

ÉDOUARD DOIGNEAU

9I Guardian of the Camargue

JEAN-GABRIEL DOMERGUE

92 The Frog or the Interrupted Tollette

GEORGES DUFRÉNOY

93 Still Life

Lent by Galerie E. Druet

94 Parodi Fountain, Genoa

Lent by Galerie E. Druet

PAUL-MICHEL DUPUY

95 A Camp of Nomads, Alicante

EUGÈNE-ANTOINE DURENNE

96 Breakfast in the Garden

Lent by Messrs. Durand-Ruel

97 A Child Writing

Lent by Messrs. Durand-Ruel

\section{CHARLES DUVENT}

98 Boats on the Giudecca Canal, Venice 


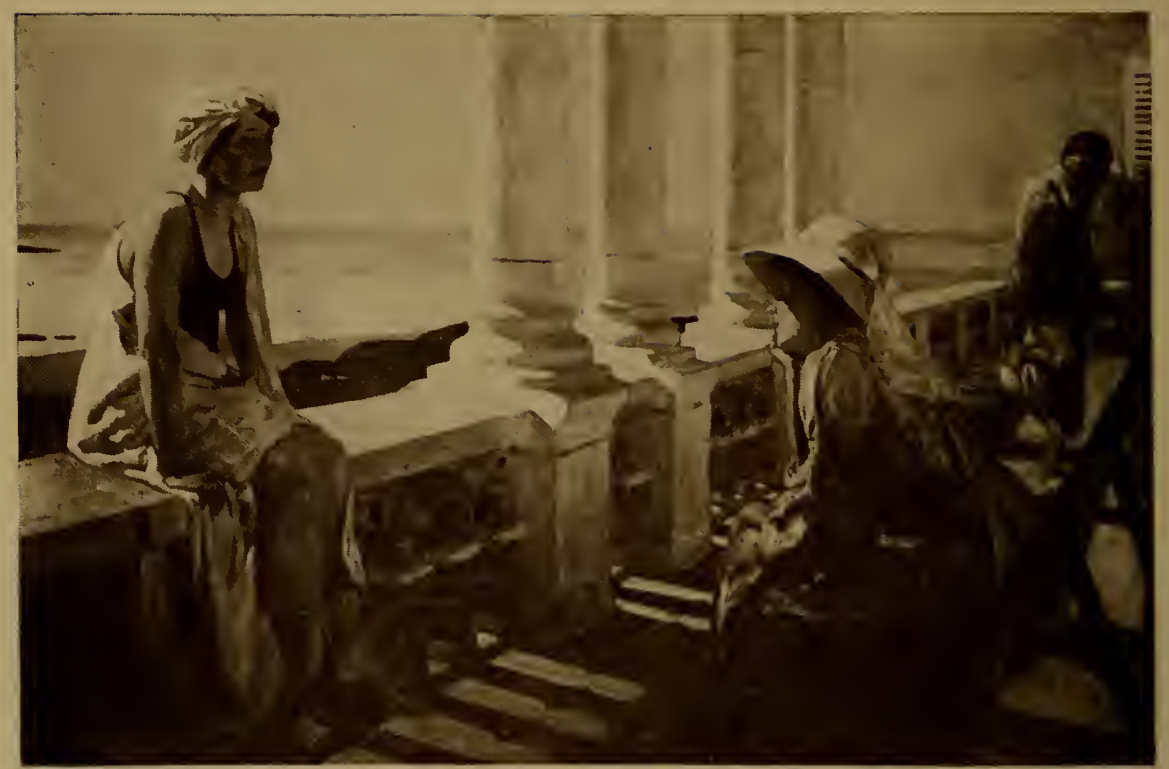

RAOUL DU GARDIER

II2 A Summer Morning 


\section{HENRI D'ESTIENNE}

99 Arab Girl Carrying Bread

HUBERT-DENIS ETCHEVERRY

ioo Corner of the Market Place, Granada

JULES-ABEL FAIVRE

IOI Parisian GirL

IO2 Girl with a Hat

HENRY FARRÉ

IO3 Portrait of My Mother

ADOLPHE FAUGERON

IO4 Night in Venice

ERNEST FILLIARD

I05 Dahlias

IO6 RED Roses

FRANÇOIS FLAMENG

IO7 Venetian Fête

HENRI FOREAU

io8 Funeral of a French Soldier

JEAN-LOUIS FOUGEROUSSE

iog Marionnettes; The Attack

CHARLES FOUQUERAY

i io The Invincible Armada

LOUISE GALTIER-BOISSIÈRE

i I Musical Instruments

RAOUL DU GARDIER

il 2 A Summer Morning 


\section{EUGÈNE HENRI GAUGUIN}

i I2A LANDSCAPE, Brittany

E. LOUIS GILLOT

i 3 Notre Dame, Paris

CHARLES GODEBY

il 4 Autumn Sunlight; Douarnenez, BRITTANY

ALBERT GOSSELIN

i 5 The Bridge, Hulay

GEORGES GRIVEAU

il 6 Women at the Bath

i 7 The Church in the Clouds

il 8 The Silver Thread of the Marne

Lent by the French Government

\section{LUCIEN GRIVEAU}

in Cows at the Pond; September

HENRY GROSJEAN

I2O The Lowlands of the Valromey

JULES GRÜN

i2 I Girl with a Glass of Water

CHARLES GUÉRIN

I22 Man with a Gourd

Lent by Galerie E. Druet

I23 Silver Goblets

Lent by Galerie E. Druet

I24 The Bouquet

Lent by Galerie E. Druet 


\section{GASTON GUIGNARD}

i25 Cavalry Maneuvers, 1808

\section{ALBERT GUILLAUME}

126 A Showman's Speech

127 AT DrILL

HENRI GUILLAUME

$$
\text { Water Colors }
$$

128 Neptune Fountain, Versailles

I29 Versailles

I3O Roman Church

I 3 I Auvergne

I32 Chateau Renaissance

133 Espalon

I 34 VERSAILles VASE

I35 Peasant House

I 36 Senlis Farmyard

137 Sunset, Luxembourg, Paris

I 38 In the Court

i39 Entrance to the Palace of Horticulture

i 40 Netherlands Pavilion

i 4 I California Building

142 Palace of Fine Arts

I43 The Tower of Jewels

I 44 Court of THE UNiverse

i 45 Horticultural Hall

i46 California Gardens

147 The Tower of Progress

I 48 Arch OF the Occident 


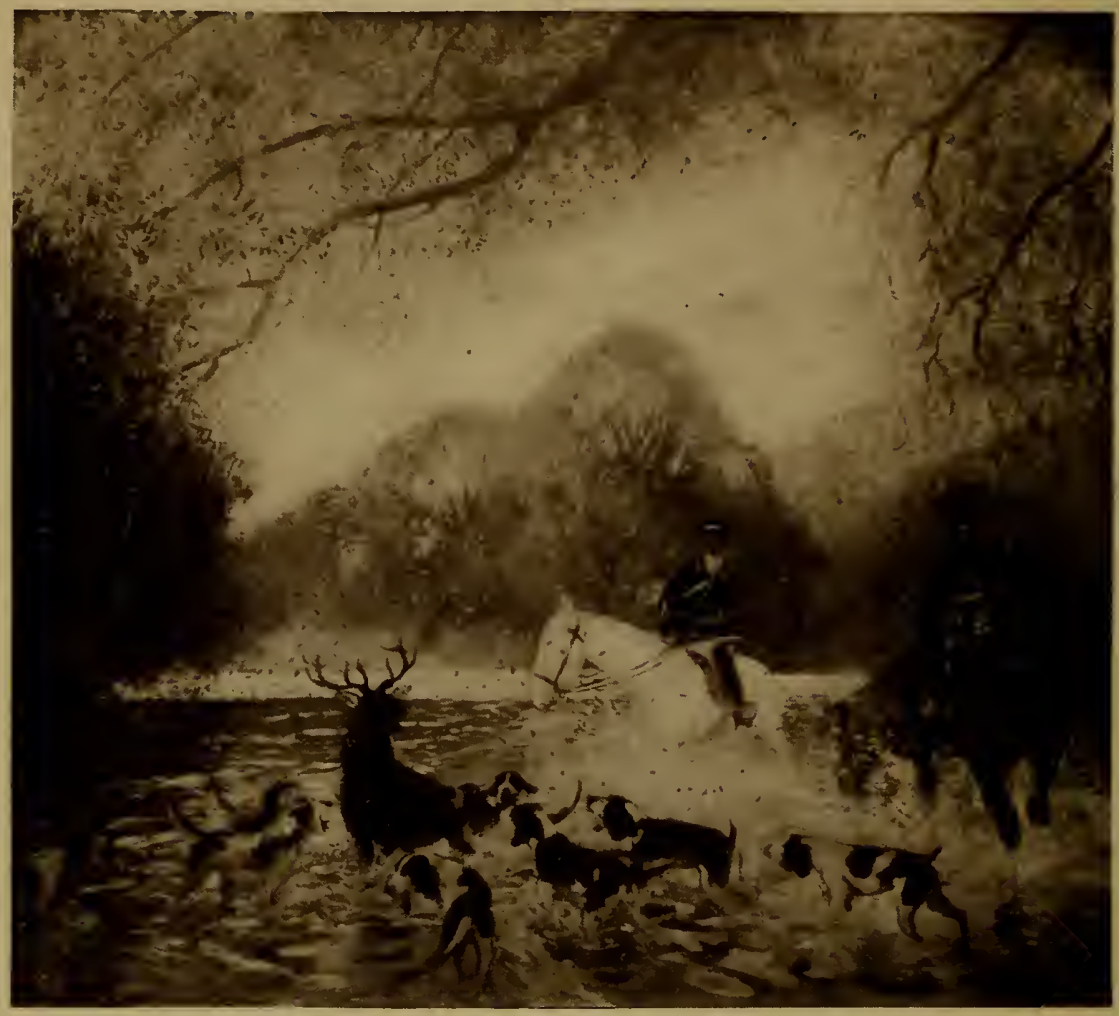

GASTON LA TOUCHE I64 HaLLALI 
ROGER-GUILLAUME

I 49 Winter, Holland

ANTOINE GUILLEMET

I 50 MoOnRise

Lent by the French Government

I5 I The Old Mills of Moret

OCTAVE GUILLONNET

152 The Peacock Fountain

\section{AUGUSTIN HANICOTTE}

i53 Winter Scene in the Low Countries

\section{PAUL HELLEU}

I54 The Cathedral of Rheins (Before the Bombardment)

CHARLES HOFFBAUER

155 Banks of the Nile

Lent by M. Knoedler, Paris

156 The Metropolitan Tower at Night Lent by M. Knoedler, Paris

PIERRE-GEORGES JEANNIOT

i57 Alone

158 The Return of the Fisherien

FRANCIS JOURDAIN

I 59 VERDURE

Lent by Galerie E. Druet

i6o Still Life

Lent by Galerie E. Druet 


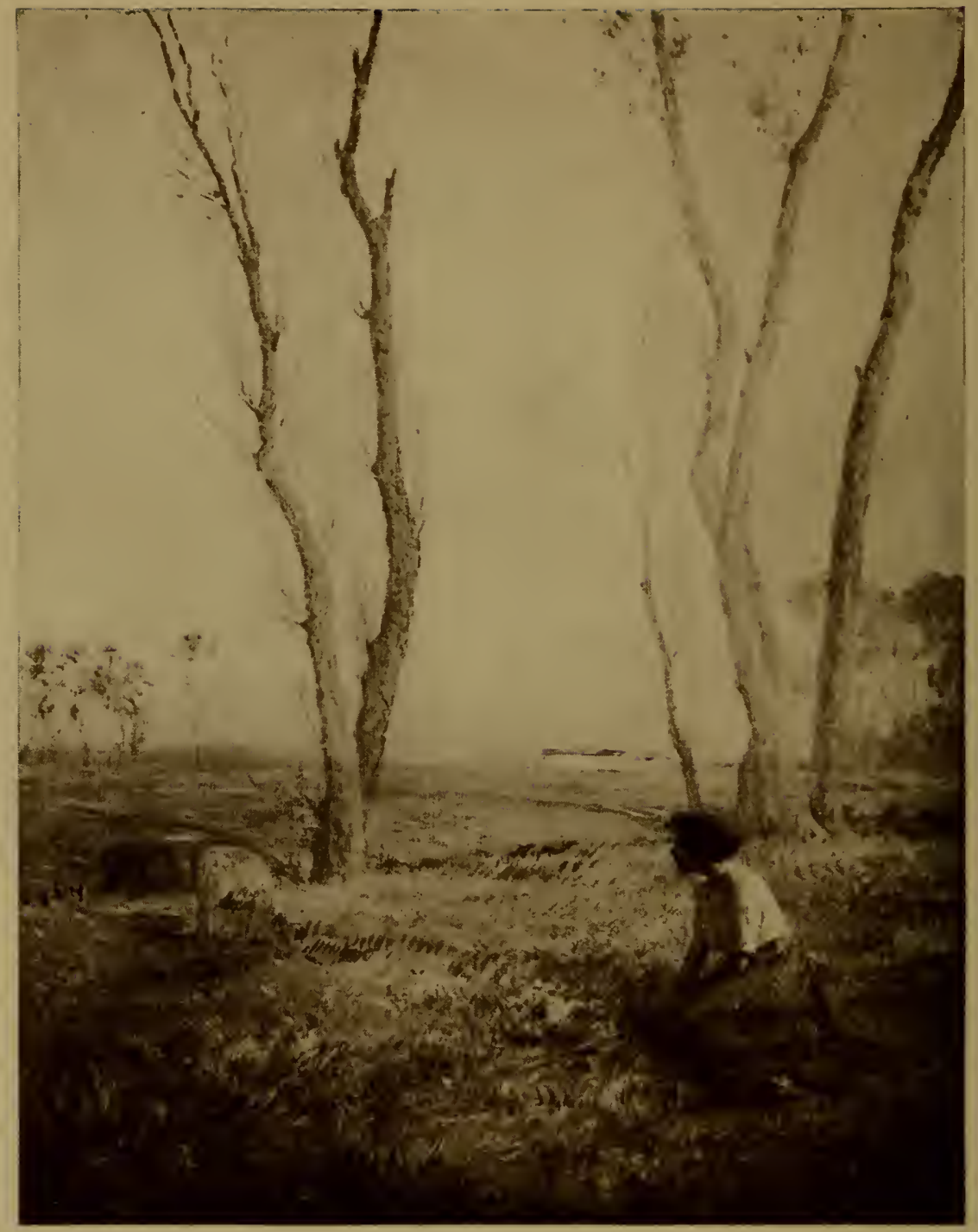

HENRI LEROLLE

173 Rosy Morning 
ANDRÉE KARPELÈS

i6I A Fakir of the Jungle

PIERRE LAPRADE

162 Still Life

Lent by Galerie E. Druet

163 Oranges

Lent by Galerie E. Druet

GASTON LA TOUCHE

I64 HaLLALI

i65 A Summer Night

LOUIS LAVALLEY

i66 Portrait Group

LOUISE LAVRUT

167 Portrait of Senator Borne

FERNAND LE GOUT-GÉRARD

168 The Pardon of Saint Anne de la Palud, Brittany

\section{GEORGES LEPAPE}

i69 Penelope Water Color

I 70 Gilles Water Color

I71 Fancy BaLL Water Color

JOSEPH LÉPINE

i72 Argentat on the Dordogne

HENRI LEROLLE

I73 Rosy Morning 


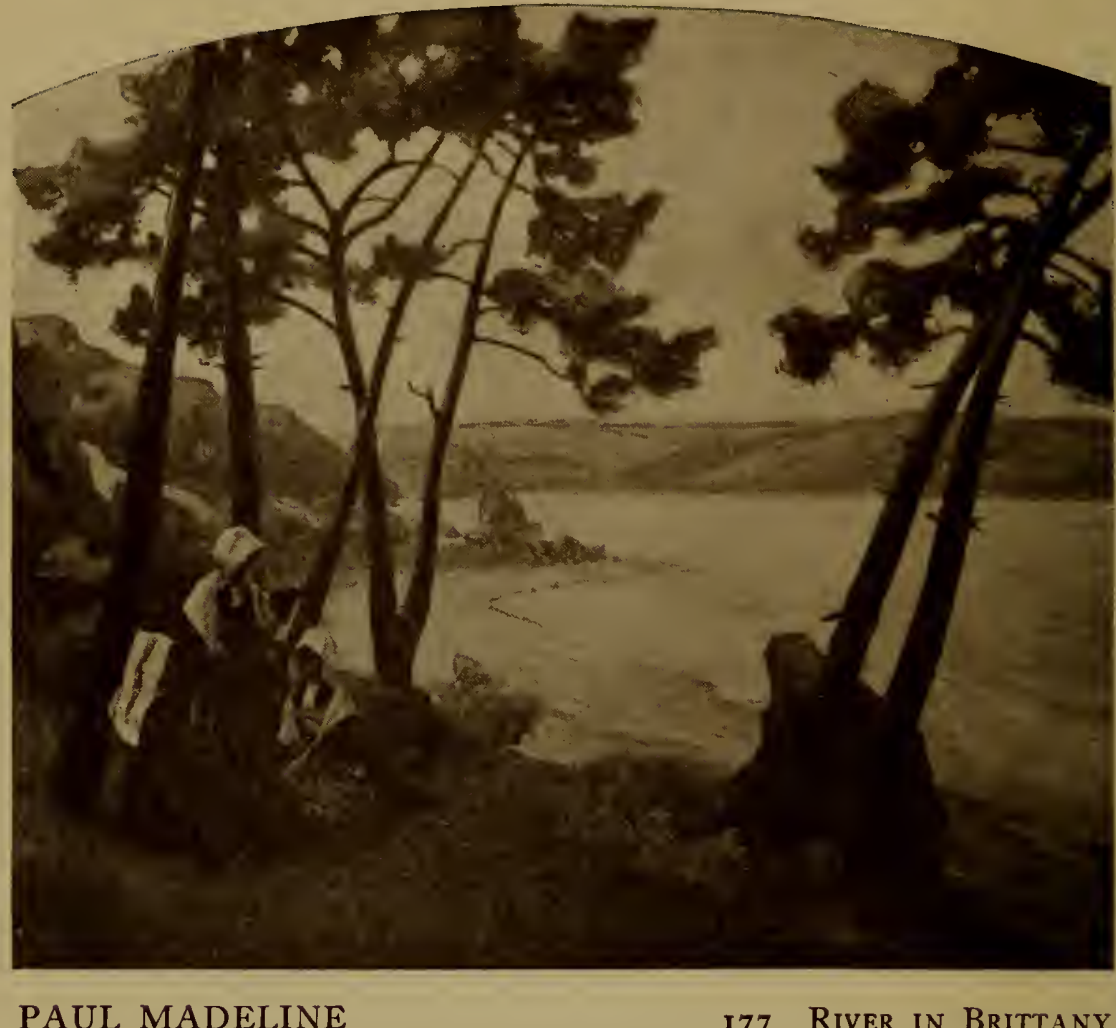

PAUL MADELINE

177 River In Brittany 
GEORGES-PAUL LEROUX

174 The Lake

175 Luxembourg Garden

MAXIMILIEN LUCE

i76 Unloading: Quai D'Auteuil

PAUL MADELINE

I77 River in Brittany

I78 The Genétin Mill

DIOGÈNE MAILLART

I79 Domesticity

FERNAND MAILLAUD

i80 Autumn Landscape, Vallée Noire

HENRI MANGUIN

18I Girl with Red Slippers

i 82 Landscape: Cassis-Sur-Mer

ALBERT MARQUET

I83 The Port of Rotterdam

Lent by Galerie E. Druet

184 The Port of Rotterdam

Lent by Galerie E. Druet

\section{CHARLES MARTIN}

I85 Beneath the Temple

HENRI-JEAN-GUILLAUME MARTIN

I86 The Lovers

I87 My Portrait

ANDRÉ MARTY

i88 The Crinoline Water Color 


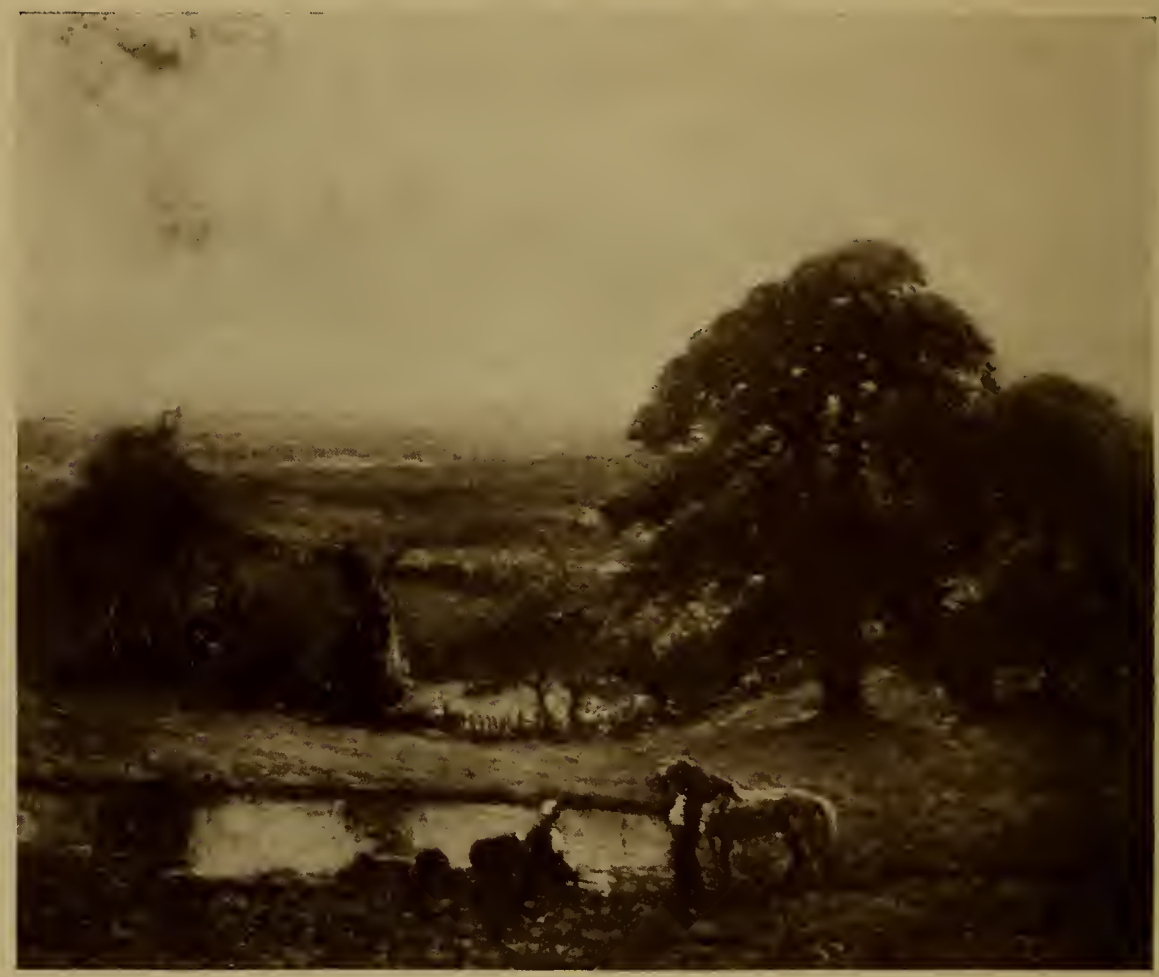

FERNAND MAILLAUD i8o AUtumn LANDScape, Vallée Noire 
JACQUELINE-MARIE MARVAL i 89 Poppies

Lent by Galerie E. Druet

I9O Bouguet

Lent by Galerie E. Druet

AUGUSTE MATISSE

igi The Sea

MAXIME MAUFRA

192 Palm Tree Plantation, Sahara

Lent by Messrs. Durand-Ruel

MATHURIN MEHEUT

I93 ON the Beach Water Color

Lent by the Luxembourg

194 After the Storis Water Color

Lent by the Luxembourg

JEAN-LOUIS-ERNEST MEISSONIER

195 Antibes

Lent by M. Georges Petit

ANTONIN MERCIÉ

ig6 Young Parisian Girl

FERNAND-ANTONIN MERCIÉ

i97 The Bridge, Toulouse; Moonrise

CHARLES MILCENDEAU

ig8 Washerwomen on the Marne

CLAUDE MONET

199 VÉTHEUIL

Lent by Messrs. Durand-Ruel 
ALEXANDRE NOZAL

200 Clouds; Pool of Saint-Quentin

FERDINAND OLIVIER

2OI The Old Mirror

Lent by the French Government

RÉNE PIOT

202 FlOWERS

203 Design for a Fresco Pencil Drawing

204 The Forum Water Color

AUGUSTE-EMMANUEL POINTELIN

205 A Hillside in the Jura

MAURICE RÉALIER-DUMAS

206 Roman Wall, Seville

ODILON REDON

207 FLOWERS

Lent by M. Joseph Hessel

ÉMILE RENARD

208 EvENING

PAUL RENAUDOT

209 The Red Jacket

2 io The Red Peignoir

PIERRE-AUGUSTE RENOIR

2i I A Garden, Rue Cortot

Lent by Messrs. Durand-Ruel 
ALFRED-PHILIPPE ROLL

2 I2 A Summer's Day

213 Fighting Horses

214 IN Belgium

215 Woman and Child

216 Self-Portrait

KERN-XAVIER ROUSSEL

217 Eurydice Stung by the Serpent

Lent by M. Joseph Hessel

2 I 8 IDYLL

Lent by M. Joseph Hessel

219 SPRING

Lent by Messrs. Bernheim

DANIEL SAUBÈS

220 The Viaticum

PAUL SIGNAC

22 I Venice; Sails

Lent by Messrs. Bernheim

222 La Rochelle: The Channel Water Color

Lent by Messrs. Bernheim

\section{LUCIEN SIMON}

223 THE Bath

Lent by Messrs. Bernheim

224 The Gondola Gouache

Lent by Messrs. Bernheim

JEANNE LUCIEN SIMON

225 Sainte Tranquilline Water Color

OLGA SLOM

226 Gulf of Porto, Corsica Water Color 


\section{ALFRED SMITH}

227 The Creuse in Winter

228 Creuse: A Winter Sun

GEORGES-FRANCOIS SOUILLET

229 The Fête of Pallio, Sienna, July 2, 1913

EDMOND SUAU

230 The Cup of Tea

23I Still Life

FRANÇOIS THÉVENET

232 Dressing; Little "Rats" of the Opera

JEANNE-HENRIETTE TIRMAN

233 The Little Ardennaise

HENRI DE TOULOUSE-LAUTREC

234 Woman at Her Tollet Water Color

FÉLIX VALLOTON

235 Reading

Lent by the Galerie E. Druet

236 Painters

Lent by the Galerie E. Druet

ÉDOUARD VUILLARD

237 Woman in a Wood

Lent by M. Joseph Hessel

238 The Lawn

Lent by Messrs. Bernheim

HENRY DE WAROQUIER

239 LILY

HENRI ZO

240 The Patio 


\section{PRINTS}

EUGÈNE BÉJOT

24I The Sully Bridge Etching

242 Rouen Etching

243 Saint-Bernard Bridge Etching

JACQUES BELTRAND

244 The Deer Park Wood Engraving

245 Landscape with Rabbits $W$ ood Engraving

JACQUES-PIERRE-VICTOR BEURDELEY

246 LANDSCAPES Etchings

BERNARD BOUTET DE MONVEL

247 The Return from the Market Color Engraving

JEAN-LOUIS BRÉMOND

248 The Cloud Etching

249 Under the Pines; Cliffs at Caux Etching

ALFRED-JEAN MARIE BROQUELET

250 The Pond After Corot Lithograph

LOUIS-ALFRED BRUNET-DEBAINES

25 I The Ponds, Ville D'Avray After Corot Etching

LOUIS BUSIÈRE

252 The Madonna of Saint Jerome After Correggio Steel Engraving

\section{AIMÉ-EDMOND DALLEMAGNE}

253 The Rue Malpalu, Rouen Etching 
ANDRÉ DAUCHEZ

254 Route de la Palud Etching

255 Chapel of Saint Guido Etching

PIERRE GUSMAN

256 A Frame Containing Three Original Woodcuts In Camayeu

CHARLES-JEAN HALLO

257 Ironclad in Action Etching

258 The Wings at the Opera Etching

FRÉDÉRIC-AUGUSTE LAGUILLERMIE

259 September Morn After Chabas Dry Point

GASTON DE LATENAY

260 The Pond Etching

GUSTAVE LEHEUTRE

26i The Sluice of the New Canal at Troyes Etching

262 Cottages at Saint André Etching

GEORGES LE MEILLEUR

263 The Cathedral of Rouen Etching

264 The Road to FréQuienne Etching

ALEXANDRE LUNOIS

265 MOORISH Dancers Lithograph

ACHILLE OUVRÉ

266 Portrait of J. H. Rosny the Elder

Color Engraving

GEORGES PROFIT

267 Portrait of Madame de Pompadour After Boucher Etching 


\section{SGULPTURE}

ALBERT BARTHOLOME

268 Mourner: Study for His "Monument TO THE DEAD"

269 At the Water's Edge

270 'The Awakening

JOSEPH BERNARD

27I GirL with Water Jar

HENRI BOUCHARD

272 Woman Nursing a Child

ÉMILE BOURDELLE

273 BeEthoven

ANTONIN CARLÈS

274 Field Flower

FERNAND DAVID

275 The Violinist

LOUIS DEJEAN

276 Woman Seated

JULES DESBOIS

277 WiNTER

GEORGES GARDET

278 Sleeping Tiger

JEAN-BOUCHER

279 Fra Angelico 
GUSTAVE LAMBERT

280 Intaglios: Eleven Engraved Gems and

REPLICAS

RAOUL LAMOURDEDIEU

28I The Needle

\section{PAUL-MAXIMILIEN LANDOWSKI}

282 Dancer with a Serpent

ALPHONSE LEGROS

283 Torso of a Young Girl

Lent by the Luxembourg

ALBERT MARQUE

284 Recumbent Woman Nursing Child

285 Child Awakening

MARIUS-JEAN-ANTONIN MERCIÉ

286 Michael-Angelo

ÉDOUARD FÉLICIEN-EUGÈNE NAVELLIER

287 Alzonne

HENRI PERNOT

288 Their Sunday; $Z$ eeerrugge, Belgium

PIERRE ROCHE

289 LoÏE Fuller 


\section{AUGUSTE RODIN}

Lent by the Luxembourg

290 FALGuière

29 I Severed Head of John the Baptist

292 Eugène Guillaume

293 Alphonse Legros

ALFRED-PHILIPPE ROLL

294 Flemish Girl

YVONNE SERRUYS

295 Dancer with a VeIL

296 Woman with a Cup

\section{JEAN TARRIT}

297 The Road to Fez 


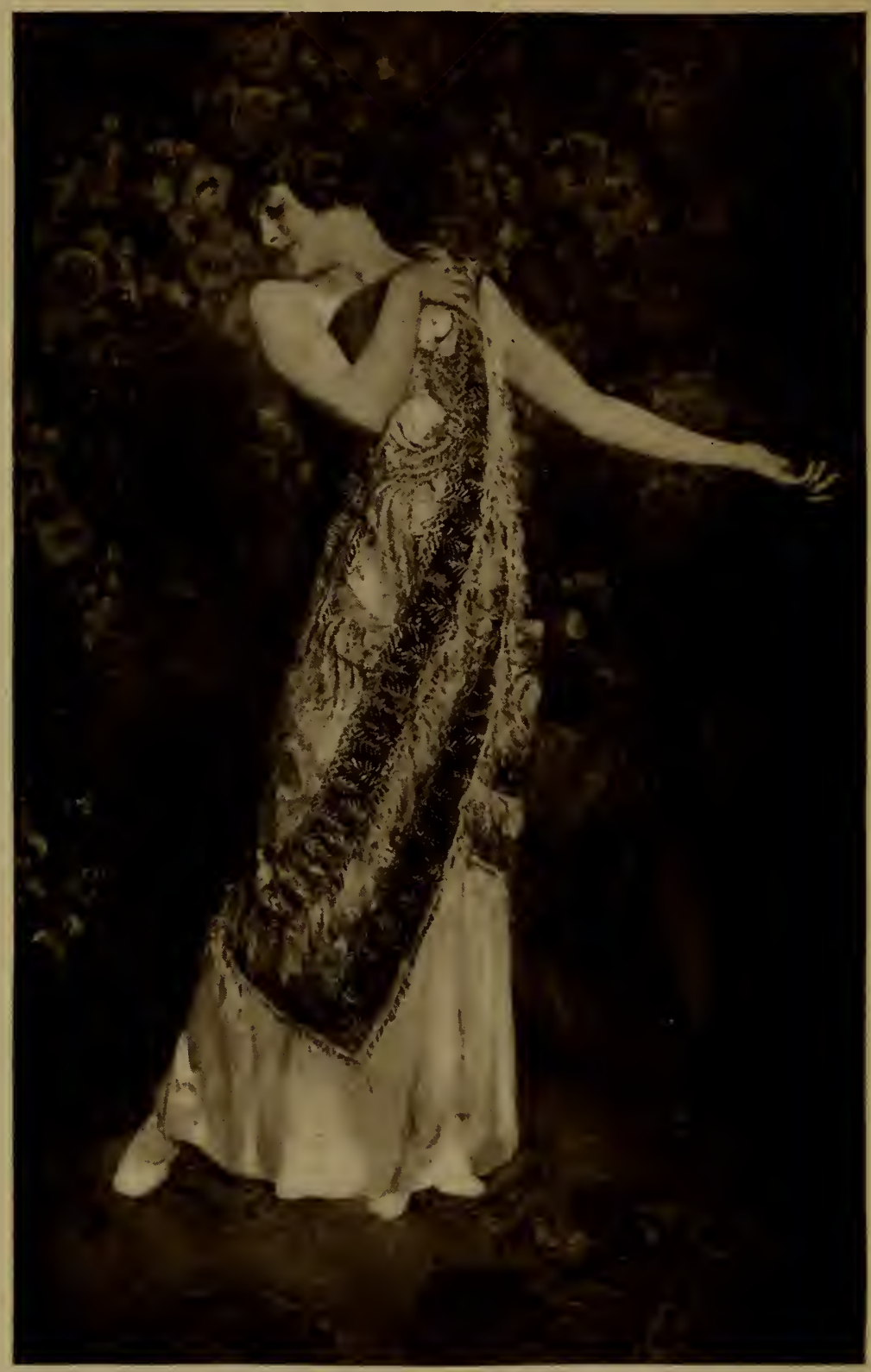

HERMAN RICHIR

316 The Red Shawl 


\title{
PAINTINGS, WATER GOLORS AND ETCHINGS BY BELGIAN ARTISTS
}

\author{
ALBERT BAERTSOEN \\ 298 Mining Country Under Snow, Liège \\ HENRI CASSIERS \\ 299 The River at Edan \\ 300 The Belfry \\ 30i A Summer Day at Volendam \\ Lent by M. Georges Petit
}

FRANTZ CHARLET

302 Dressing Baby

VICTOR GILSOUL
303 Evening in Antwerp
304 Dunes at Nieuport
305 The Grand Place, Brussels
306 Corner in a BÉguinage
307 View from the Artist's Studio in Brussels
308 Evening, Beaulieu

MODEST HUYS

309 The Market at Audenaerde

CAMILLE-NICHOLAS LAMBERT

3 Io Twilight at SEa 
ALEXANDRE MARCETTE

3 I I Fishing-Boats; Night Scene

3 I2 Storm in the Dunes, Nieuport

Lent by Messrs. Chaine $ซ$ Simonson

313 Fishing Boat in Nieuport Channel

ISIDORE OPSOMER

3 I 4 Church of the Béguinage, Lierre Color Etching

PIERRE PAULUS

315 Saint Paul's Cathedral, London

HERMAN RICHIR

316 The Red Shatvl

3I 7 LOOKING Backivard

ALICE RONNER

318 Gillyflowers

THÉODORE VAN RYSSELBERGHE

319 The Path of Ste-Brelade, Jersey

320 Fountain in the Garden of the

Generalife, Granada

32 Garden of the Generalife, Granada 




\section{G U I D E T O IN S T A L L A T I O N S}

\section{GURRENT SPECIAL EXHIBITIONS}

An Exhibition of Portraits by American Artists galleries 18 and 19 An Exhibition of Works by French and Belgian Artists galleries $20,25,26,27,30,31$ and 32

\section{OTHER COLLEGTIONS}

Recent Acquisitions . . . . . . . . . . . . . . . . . . . . gallery 1 Paintings, recent acquisitions, chiefly in ............... galleries 2 and 3 Paintings belonging to the W. K. Bixby American Art Acquisition Fund

Collection.................................... 15 Paintings......................

Print Collection: Etchings, Engravings, Lithograplss, Arundel and other prints......................... second floor, south galleries

Greek Sculpture.......................... galleries 17 and 24

Roman and Renaissance Sculpture........................... gallery 8 and northwest alcove of central sculpture hall.

Antique Bronzes..................nstalled decoratively in various galleries Modern Sculpture.................. principally in central sculpture hall Modern Bronzes. . . . . . . . . . . . . . . . . . . . . . . . . . 28 Medallions, in cases....................... second floor, west gallery Egyptian and Assyrian Antiquities, including sculpturebasement, east galleries

Copper Plates, Coins, Medallions, lent by Mr. J. M. Wulfingsecond floor, west gallery

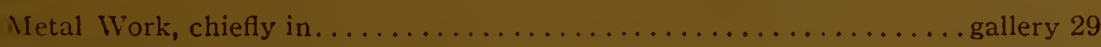

Pottery, chiefly in ........................................ 13 also in ...................... galleries 10,11 and 22

Ceramics by M. Taxile Doat, in . . . . . . . . . . . . . . . gallery 12

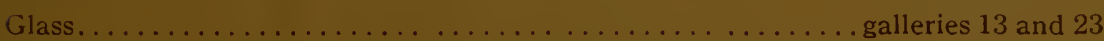
St. Elizabeth Mosaics (presented by Adolphus Busch, 1905)-

central sculpture hall Fabrics, etc., chiefly in ...................... alcove $\mathrm{H}$ and gallery 13 also in Indian and other collections.

Examples of wood carving. . . . . . . . . . . . . . . . . . . . . 21 American Indian Handiwork, Dyer Collection.......... basement, east galleries Ezra H. Linley Collection................................. gallery 22 Japanese and Chinese Art, chiefly in ................. galleries 10 and 11 
FREE EVIRY DAY IN THI YEAR. OPFNING AT TIN A.M CLOSING AT FIVE P.M.

'I'he Special, Exhibitius Cataiogl lo of the City Art Meseum may be subscribed for BY THE YFAR at a nominal price of ONE DOI.I.AR, which should be sent to the Secretary, with the mailing address of the suliscriber

The Illustrated BULitetil of the City Art Museum will be mailed to any address at the subscription price of hfty cents a year. It supplies information as to coming exhibitions and other activities. 